\section{ECONOMICS}

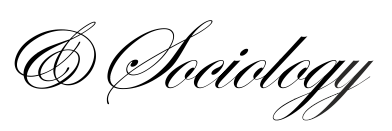

\title{
PRODUCTION FUNCTION AND PRODUCT AND LABOR MARKET IMPERFECTIONS IN SLOVENIA: AN INDUSTRY-LEVEL PANEL APPROACH
}

\author{
Silvo Dajcman, \\ Faculty of Economics and Business, \\ University of Maribor, Slovenia \\ E-mail:silvo.dajcman@um.si
}

Received: March, 2018

1st Revision: May, 2018

Accepted: September, 2018

DOI: $10.14254 / 2071-$

789X.2018/11-3/21

\begin{abstract}
Following recent advances in the panel time-series data analysis, this paper estimates the aggregate production function for Slovenia using industry-level data, thus allowing for variable non-stationarity, cross-industry heterogeneity and dependence. The production function parameter estimates are then used to calculate the joint (product and labor) market imperfections parameter developed by Dobbelaere and Mairesse (2013). The results illustrate that: 1) a constant return-to-scale assumption can be imposed on the aggregate production function, 2) industry-level output elasticities with respect to inputs are heterogenous, 3) the joint market imperfections parameter indicates that, on average, Slovenia's producers' output markets can be characterized as imperfect, and 4) the labor markets features the "efficient-bargaining" labor model characteristics.
\end{abstract}

Keywords: production function; heterogeneity; cross-sectional dependence; labor and output market imperfections
JEL Classification: D02, O17, P31

\section{Introduction}

In this article, the empirical aggregate production function for Slovenia is developed and estimated in relation to recent developments in the panel time-series literature (Pesaran, 2006, 2007; Chudik \& Pesaran, 2013; Holly et al., 2010; Eberhardt \& Teal, 2010b). An estimation of the output and labor market imperfections in Slovenia, following the approach of Dobbelaere and Mairesse (2013), will also be conducted.

The increased availability of detailed national accounts data and the development of non-stationary heterogenous panel model estimators has revived the empirical research on the aggregate cross-country production function (Pedroni, 2007), cross-country sector and industry production functions (Mundlak et al., 2008; Eberhardt \& Teal, 2010a, 2010b, 2012, 2013, 2017; Baccianti, 2013), aggregate country production function based on regional data (Constantini \& Destefanis, 2009; Carrion-i-Silvestre \& Surdeanu, 2012, 2016; Benos et al., 2017), and the national sectoral production function based on industry data (Baptist \& Hepburn, 2013). These studies commonly model production function parameters as heterogenous (throughout the paper, we use the terms production function heterogeneity and production technology heterogeneity as synonyms), contrary to the Solow-Swan neoclassical production function framework. 
Theoretically, the heterogenous production function technology across countries is recognized by the new growth models (Durlauf, 1993; Durlauf et al., 2001; Temple, 2005; Eberhardt \& Teal, 2012). Heterogenous technology across-sectors/industries is recognized also by theoretical contributions of Lewis (1954), Mundlak (1993), Mundlak et al. (2008), Vollrath (2009) and the structural change literature (Baumol, 1967; Baumol et al., 1985, Laitner, 2000; Uy et al., 2013). Krüger (2008) provides a list and review of these studies, while Uy et al. (2013) presents a list of the recent studies in this strand of the literature.

Several authors have stressed that an aggregate production function cannot be estimated with an empirical model that does not allow for heterogeneity (Temple, 2005; Banerjee \& Duflo, 2005; Vollrath, 2009; Eberhardt \& Teal, 2012). This critique renders the time series modelling approach inappropriate. However, as noted in Eberhardt and Teal (2010b), in the empirical modelling of the production function, capturing heterogeneity is not enough, because industries are very likely to be interdependent, due to common economic shocks, political shocks, and trade linkages. If the cross-sectional dependence is not correctly captured in the empirical model, the production function estimates may be inconsistent (Pesaran, 2006, 2007; Chudik \& Pesaran, 2013).

Conventional panel model estimators (e.g., ordinary least squares (OLS), fixed effects), cannot account for heterogeneity and dependence across cross-section units (Eberhardt and Bond, 2009). We note that the results of the empirical studies (Eberhardt \& Teal, 2010a, 2010b, 2013; Pedroni, 2007; Carrion-i-Silvestre \& Surdeanu, 2012) confirm the heterogeneity of production technology across industries/sectors/countries, as long as the variables in the production functions are cross-sectionally dependent. To address these challenges, this paper applies the common correlated effects mean group (CCEMG) estimator of Pesaran (2006) and the augmented mean group (AMG) estimator of Eberhardt and Teal (2010b), which are robust to the listed issues. There is also another advantage of using CCEMG and AMG over the conventional panel data estimator. Pedroni (2007) notes that aggregate production function variables are often non-stationary. Unlike conventional panel data estimators, the CCEMG and AMG estimators can consistently estimate a long-run relationship between the output and the production function inputs.

A strand of the literature (Dobbelaere \& Mairesse, 2013; de Loecker \& Warzynski, 2012), building on the seminal work of Hall (1988), has developed theoretical models that jointly determine the output and labor market imperfections, based on the product function parameter estimates. In particular, Dobbelaere and Mairesse's (2013) model illustrates how the estimates of the output elasticities, with respect to the labor and intermediate inputs (materials), can be used to estimate a joint output (product) and labor market imperfections parameter. This is accomplished by comparing the estimated elasticities with the factor shares in the output. The empirical applications of the model (Dobbelaere \& Mairesse, 2013; Dobbelaere et al., 2015; Dobbelaere \& Kiyota, 2017; Damoah, 2017) relate the output to three input factors: labor, capital and material (intermediate) inputs. It is revealed that different degrees of joint market imperfections occur in different industries. The studies, however, use conventional panel data estimators (e.g., ordinary least squares (OLS), fixed effects, General Method of Moments), which are not robust to issues identified by the panel time-series literature (Holly et al., 2010; Pesaran \& Tosetti, 2011; Banerjee \& Carrion-i-Silvestre, 2017), especially to cross-sectional heterogeneity and dependence.

The literature on the aggregate production function estimation for Slovenia is thin (Novak, 2003; Jongen, 2004; Novak \& Bojnec, 2005; Jemec, 2012). Jongen (2004) and Jemec (2012) use time series data to estimate the potential GDP and the contribution of input and total productivity growth to national economic growth. They assume a Cobb-Douglas production function and do not estimate but assume the GDP elasticities with respect to labor (Jongen (2004) assumes 0.7 and Jemec (2012) assumes 0.67) and capital (0.3 and 0.33, 
respectively). Novak (2003) applies time series data to estimate three aggregate production function specifications and then estimates the sources of economic growth. The estimates for the elasticity of GDP, with respect to labor, range from 0.13 to 0.35 . For labor, the range is 0.45 to 0.87 . Novak and Bojnec (2005) estimate the aggregate and municipalities production function, applying both time series and cross-section data. They estimate an aggregate average production function using OLS. They determine the elasticity of GDP with respect to labor as 0.5 and with respect to capital as 0.31 . For the aggregate marginal stochastic frontier production function estimated by the maximum likelihood method, the results are 0.3 and 0.5 , respectively.

To our knowledge, Molnar (2010) is the only that investigates incompleteness in the product (output) markets across the Slovenian industries. The study uses firm-level data for the period of 1993-2006 and applies Roeger's (1995) method to estimate the level of incompleteness in the product (output) market in the manufacturing and service industries by estimating the mark-ups. The results of the study illustrate that mark-ups are, on average, higher than in other OECD countries. Mark-ups are also diverse across industries and higher in industries with a higher degree of information asymmetry.

The objective of this research is to estimate the aggregate production function for Slovenia by applying a panel econometric framework on the industry data for the period of 2000 through 2016. Unlike the existent studies we allow production function heterogeneity across industries, and control for cross-sectional dependence, and possibly, spurious regression. These issues are not dealt with sufficiently in the existing studies on market imperfections. In addition, in the tradition of the market imperfection literature, we model a three-inputs production function composed of labor, capital and intermediate inputs. In this respect Hall et al. (2009) and Dobbelaere and Mairesse (2013) argue that gross output should be used, instead of value added (GDP), in the production function. Thus, the intermediate inputs should be among the explanatory variables. Baptist and Hepburn (2013) further argue that, in the age when natural resources are becoming scarcer, the intermediate inputs should be recognized in macroeconomic models as an important production factor.

This paper is the first attempt to estimate the joint product and labor market imperfections in the Slovenian economy.

The remainder of the paper is organized into three sections: the presentation of the methodology, the data and empirical results, and the conclusions.

\section{Methodology}

The empirical research consists of two parts. The first part obtains an estimate of the aggregate production function for Slovenia, based on industry-level data. The function is robust to the issues of cross-sectional dependence, cross-sectional heterogeneity and variable non-stationarity. The second part of the study consists of estimating the joint product and labor market imperfections parameter developed by Dobbelaere and Mairesse (2013). These imperfections estimates are based on the production function parameter estimates from the first part of research.

Following Hall (1988), Dobbelaere and Mairesse (2013), and Damoah (2017), we assume the following production function:

$$
Q_{i t}=A_{i t} F\left(L_{i t}, K_{i t}, M_{i t}\right) \text {, }
$$

where $i$ denotes panel cross-section units (industries, $i=1, \ldots, N), t$ denotes time (in years; $t=1, \ldots, T), Q_{i t}$ is the gross output, dependent on the inputs labor $\left(L_{i t}\right)$, capital stock $\left(K_{i t}\right)$, and intermediate inputs $\left(M_{i t}\right) . A_{i t}$ is the total factor productivity, capturing all unobservable 
factor(s) affecting output. Total factor productivity is thus a "measure of ignorance" instead of efficiency (see e.g. Abramowitz, 1956; Mankiw et al. 1992; Eberhardt \& Teal, 2010b, 2013; Carrion-i-Silvestre \& Surdenau, 2012).

Let the empirical production function be determined in per capital terms. Dividing the previous specification by input factor $K_{i t}$, taking the logarithms, and, for simplicity which will be relaxed in the estimation of the model, assuming the Cobb-Douglas production function (this implies that returns to scale are constant; the constant returns to scale (CRS) assumption can be tested by estimating equation $q_{i t}=\alpha_{L i} l_{i t}+\alpha_{M i} m_{i t}+\gamma_{K i} l n K_{i t}+u_{i t}$ and then evaluating the slope $\gamma_{K i}$. The constant returns to scale can be rejected if the slope coefficient is significantly negative (see Eberhardt \& Teal, 2012, 2013)), the following empirical production function can be specified (see Dobbelaere \& Mairesse (2013); Carrion-i-Silvestre \& Surdenau, (2012)):

$$
q_{i t}=\alpha_{L i} l_{i t}+\alpha_{M i} m_{i t}+u_{i t}
$$

where $q_{i t}=\ln \left(\frac{Q_{i t}}{K_{i t}}\right), l_{i t}=\ln \left(\frac{L_{i t}}{K_{i t}}\right), m_{i t}=\ln \left(\frac{M_{i t}}{K_{i t}}\right), \quad \alpha_{L i}$, and $\alpha_{M i}$ are output elasticities with respect to labor, and intermediate inputs. The implied output elasticity with respect to capital can be obtained post-estimation as $\alpha_{K i}=1-\alpha_{L i}-\alpha_{M i}$. Specification (2) allows for heterogeneous elasticities of output to inputs across industries, but assumes they are constant through observed time period. $u_{i t}$ is the error term, specified as (Eberhardt \& Teal, 2010a, 2012; Carrion-i-Silvestre \& Surdenau, 2012):

$$
u_{i t}=\alpha_{i o}+\beta_{i} t+\lambda_{i}^{\prime} \boldsymbol{f}_{t}+e_{i t},
$$

where $\alpha_{i o}$ is the industry constant, $\beta_{i} t$ the industry time trend (a country trend is included in order to capture "omitted idiosyncratic processes evolving in a linear fashion over time, see Eberhardt and Teal (2010b), $\boldsymbol{f}_{t}$ denotes a vector of common unobserved factors (e.g. economic or financial crises, changes in economic policy or regulation etc. that affect all industries), responsible for the cross-sectional dependence between industries, with slopes allowed to differ across industries $\left(\lambda_{i}^{\prime}\right)$, and $e_{i t}$ an idiosyncratic error term. Common unobserved factors may be stationary or non-stationary processes. Also, the same set of common factors may drive the data generating processes of input factors $\left(l_{i t}\right.$ and $\left.m_{i t}\right)$ as well as the output $\left(q_{i t}\right)$ (see Eberhardt and Teal 2012, 2013). The above specification (2) thus controls for endogeneity arising from common factors (see Eberhardt \& Teal, 2012).

Model (2) is general and can be estimated by the CCEMG estimator of Pesaran (2006) and the AMG estimator of Eberhardt and Teal (2010b). The estimators are proven to yield consistent estimates in the cases of cross-sectional dependence, panel heterogeneity and nonstationarity of the panel (Pesaran, 2006; Eberhardt \& Teal, 2010b; Eberhardt \& Bond, 2009; Pesaran \& Tosetti, 2011). The CCEMG estimator accounts for cross-sectional dependence through the inclusion of the cross-section averages of the model's observed variables. The CCEMG model specification of (2) is:

$$
\begin{gathered}
q_{i t}=\alpha_{L i, C C E M G} l_{i t}+\alpha_{M i, C C E M G} m_{i t}+\gamma_{0 i} \overline{q_{l t}}+\gamma_{1 i} \overline{l_{l t}}+\gamma_{2 i} \overline{m_{l t}}+\alpha_{i o, C C E M G}+\beta_{i, C C E M G} t+ \\
+e_{i t, C C E M G},
\end{gathered}
$$

where and $\alpha_{L i, C C E M G} \alpha_{M i, C C E M G}$ are the output elasticities with respect to labor, and intermediate inputs obtained as simple averages of elasticities for individual industries. The cross-sectional averages of the model's observed variables are denoted by . 
The AMG estimation of model (2) is obtained in two steps. The first step involves the estimation of the modified equation (2) by the first-difference estimator (FD-OLS), in which $T-1$ time dummy variables are added on the right side of the equation to account for spurious regression issue (Eberhardt \& Teal, 2010b). In the second step, the following model is estimated:

$$
q_{i t}=\alpha_{L i, A M G} l_{i t}+\alpha_{M i, A M G} m_{i t}+\eta_{i} \hat{c}_{t}+\alpha_{i o, A M G}+\beta_{i, A M G} t+e_{i t, A M G},
$$

where $\hat{c}_{t}$ denotes coefficient estimates of the year dummy variables from the first step estimation. Eberhardt and Teal (2010b) argue that the unobserved common factors in (5) are captured by $\hat{c}_{t}$, and explicitly estimated (unlike in the CCEMG model). $\hat{c}_{t}$ represents the "common total factor productivity evolution over time" (ibidem) which cannot be estimated by the CCEMG model. The AMG estimates of the coefficients of the input factors $\left(\alpha_{L i}\right.$ and $\alpha_{M i}$ ) and total factor productivity $\left(\eta_{i}\right)$ are obtained by taking a simple average of the individual (industry's) slope coefficients. The results of the estimations for (4) and (5) are compared with the results of the fixed effects (FE) estimator, which, in the empirical literature, is the most commonly applied panel data estimator. It is known that the FE estimator is inconsistent when the true relationship between the explanatory and dependent variables is heterogeneous, instead of homogenous (Pesaran \& Smith, 1995), and if the crosssectional dependence is not correctly accounted for (Pesaran, 2006, 2007; Chudik \& Pesaran, 2013). The FE estimator model, conducted to shed some light on the extent of the issues of heterogeneity and cross-sectional dependence between industries on the parameter estimates, is:

$$
q_{i t}=\alpha_{L i, F E} l_{i t}+\alpha_{M i, F E} m_{i t}+\alpha_{i o, F E}+e_{i t, F E} .
$$

Models (4) and (5) are estimated with Eberhardt's (2012) Stata routine, xtmg, while model (6) is estimated with the built-in Stata routine. A set of diagnostic tests are performed to compare the statistical features of the estimated models.

Under the assumptions of competitive input and output markets and the CRS, the output elasticity associated with a specific input equals its share in output production (Solow, 1957; Norrbin, 1993; Dobbelaere \& Mairesse, 2013). If, for the estimated production function, the assumption of CRS cannot be rejected, a comparison between the output elasticity associated with a specific input and its share in output production is indicative of the imperfections in the input and output markets.

Dobbelaere and Mairesse (2013) formulated the joint (product and labor market) market imperfections indicator $(\tau)$. The joint (product and labor market) market imperfections indicator $(\tau)$ is an average (across the industries) indicator of market imperfections. In our empirical framework, this indicator can be written as:

$$
\tau=\frac{\alpha_{M i}}{\overline{v_{M \imath}}}-\frac{\alpha_{L i}}{\overline{v_{L l}}}
$$

where $\alpha_{L i}$ and $\alpha_{M i}$ are unbiased average (across the industries) output elasticities with respect to the labor and intermediate inputs, estimated by equations (4)-(6); $\overline{v_{M l}}$ and $\overline{v_{L l}}$ are the across-the-industry average shares of the inputs in the total output. The authors (ibidem) show that the sign of the joint market imperfections parameter indicates one of three possible labor market regimes: an efficient bargaining labor market regime (workers and companies bargain over wages and the level of employment) $(\tau>0)$, a monopsony labor market $(\tau<0)$, and 
perfect competition in the labor market $(\tau=0)$. For the derivation of the expressions and detailed characteristics of each labor market regime, see Dobbelaere and Mairesse (2013).

Dobbelaere and Mairesse (2013) argue that competition in the product markets can be imperfect due to product differentiation, barriers to entry, or imperfect information. Empirically, the assumption of an imperfect product (output) market can be tested with the following expression:

$$
\mu=\frac{\alpha_{M i}}{\overline{v_{M l}}}
$$

where $\mu_{i t}$ is the average (across the industries) estimate of the price-cost mark-up.

\section{Data and empirical results}

Models (4)-(6) are estimated on annual data for Slovenia's NACErev2 industries for the period of 2000 to 2016. Economic activities are classified in accordance with Statistical Classification of Economic Activities in the European Community, Rev. 2 (Eurostat 2008), into 21 industries (codes and industry are listed): A Agriculture, forestry and fishing; B Mining and quarrying; C Manufacturing; D Electricity, gas, steam and air conditioning supply; E Water supply, sewerage, waste management and remediation activities; F Construction; G Wholesale and retail trade; repair of motor vehicles; $\mathrm{H}$ Transportation and storage; I Accommodation and food service activities; J Information and communication; K Financial and insurance activities; L Real estate activities; M Professional, scientific and technical activities; $\mathrm{N}$ Administrative and support service activities; O Public administration and defense, compulsory social security; P Education; Q Human health and social work activities; $\mathrm{R}$ Arts, entertainment and recreation; $\mathrm{S}$ Other service activities; $\mathrm{T}$ activities of households as employers; $U$ activities of extra-territorial organizations and bodies. Activities with codes $\mathrm{T}$ and $\mathrm{U}$ are not included in the empirical research as there are no data entries in the national accounts for Slovenia for the input capital.

The data panel is balanced. The source of the primary data on output, labor, capital, and intermediate input is the Statistical Office of the Republic of Slovenia. A description of the variables in models (4)-(6) are presented in Table 1.

A crucial part of the panel model estimation is to assure that the cross-sectional dependence is correctly accounted for. Cross-section units can be either: 1) cross-sectionally independent or 2) weak (this dependence is attributed mainly to the economic proximity of the industries) or strong cross-sectionally dependent (attributed to shocks that affect all industries (e.g., macroeconomic shocks, economic policy changes, demand shocks)) (Holly et al., 2010; Pesaran \& Tosetti, 2011; Banerjee \& Carrion-i-Silvestre, 2017). In the panel timeseries literature (Pesaran, 2006, 2007; Chudik \& Pesaran, 2013), it is argued that if unaccounted for (as is the case for conventional panel model estimators (e.g., by the pooled, fixed effects or the mean group estimator)), a strong-form of cross-sectional dependence may result in inconsistent parameter estimates. We apply the CD test of Pesaran $(2004,2015)$ to test for both the weak and the strong form of cross-sectional dependence. The results of the exercise are presented in Table 2. 
Table 1. Description of the variables used in the empirical models

\begin{tabular}{|c|c|c|}
\hline $\begin{array}{l}\text { Variables used in } \\
\text { models (4)-(6) }\end{array}$ & Variable definitions & Data source \\
\hline $\begin{array}{l}\text { Natural logarithm of } \\
\text { output per capital }\left(q_{i t}\right)\end{array}$ & $\begin{array}{l}\text { Natural logarithm of the ratio of real output (constant } \\
\text { prices with reference year 2010) of industry } i \text { to the } \\
\text { gross fixed assets in industry } i \text { at the end of year } t \text {. } \\
\text { Capital stock is proxied by the real (chain-linked) } \\
\text { gross fixed assets, as in Dobbelaere and Mairesse } \\
\text { (2013). The data on gross fixed assets are estimated } \\
\text { by the Statistical Office of the Republic of Slovenia, } \\
\text { applying the unified European Union methodology. } \\
\text { A detailed description of how the variable is formed } \\
\text { is provided in the Statistical Office of the Republic } \\
\text { of Slovenia (2017). Chain-linked volumes by } \\
\text { reference year } 2010 \text { are calculated. }\end{array}$ & $\begin{array}{l}\text { Statistical Office of the } \\
\text { Republic of Slovenia }\end{array}$ \\
\hline $\begin{array}{l}\text { Natural logarithm of } \\
\text { labor per capita }\left(l_{i t}\right)\end{array}$ & $\begin{array}{l}\text { Natural logarithm of the ratio of hours worked in } \\
\text { industry } i \text { to the gross fixed assets in industry } i \text { at the } \\
\text { end of year } t \text {. In national accounts, the data on } \\
\text { employment (in 1000) and hours worked (in 1000) } \\
\text { were available. We prefer to use hours worked, as } \\
\text { D'Auria et al. (2010) prefers this variable over the } \\
\text { alternative. }\end{array}$ & $\begin{array}{l}\text { Statistical Office of the } \\
\text { Republic of Slovenia }\end{array}$ \\
\hline $\begin{array}{l}\text { Natural logarithm of } \\
\text { intermediate inputs per } \\
\text { capita }\left(m_{i t}\right)\end{array}$ & $\begin{array}{l}\text { Natural logarithm of the ratio of intermediate } \\
\text { consumption in industry } i \text { to the gross fixed assets in } \\
\text { industry } i \text { at the end of year } t .{ }^{1} \text { Intermediate input } \\
\text { usage in production is proxied by intermediate } \\
\text { consumption, a common technique in the literature } \\
\text { (Baptist \& Hepburn, 2013; Bournakis et al. 2017; } \\
\text { Dobbelaere \& Mairesse, 2013). }\end{array}$ & $\begin{array}{l}\text { Statistical Office of the } \\
\text { Republic of Slovenia }\end{array}$ \\
\hline
\end{tabular}

Source: Own research.

Table 2. Cross-sectional dependence $-\mathrm{CD}$ test results

\begin{tabular}{lcc}
\hline \multirow{2}{*}{ Variable } & CD test statistics and the p-value & Cross(industry)-correlation \\
\hline \multirow{2}{*}{$q_{i t}$} & 10.891 & 0.38 \\
\hline \multirow{2}{*}{$l_{i t}$} & $(0.000)$ & 0.60 \\
\hline \multirow{2}{*}{$m_{i t}$} & 3.003 & 0.41 \\
\hline
\end{tabular}

Notes: The null hypothesis of the CD test is that the cross-section units (industries) are either weak or strong cross-sectionally independent. The test was performed by the Stata routine xtcdf, written by Wursten (2017). The table reports the test statistics and the corresponding p-value (in brackets) for rejection of the null hypothesis. We also present the mean absolute value of the correlation across the industries.

Source: Own research.

The results of the CD test and the mean absolute correlation illustrate that industries in Slovenia are cross-dependent. The result was expected, since the industries are linked to each other through supply chains (Han, 2016). They also share a common economic policy, as well as common domestic and international economic shocks. This finding implies that the estimation of models (4)-(6) should be performed by a panel data estimator(s) that accounts for cross-sectional dependence (i.e., CCEMG and AMG). 
In the framework of the panel data models, non-stationary and non-cointegration (spurious regression) are not as large of an issue as they are in the time series framework (Phillips \& Moon, 1999; Baltagi, 2005). This is because the conventional estimators can still be unbiased in the homogenous and cross-sectionally independent panels. Despite this, the inferences based on the t-statistics are not valid (Kao, 1999; Eberhardt \& Bond, 2009; Banerjee et al., 2010). We test for the non-stationarity of models' (4)-(6) variables using Pesaran's (2007) CIPS test.

Table 3. (Non-)stationarity of variables - the results of CIPS test

\begin{tabular}{|c|c|c|c|c|c|c|}
\hline \multirow[t]{3}{*}{ Variable } & \multicolumn{6}{|c|}{ CIPS test statistics } \\
\hline & \multicolumn{2}{|c|}{ Lag 1} & \multicolumn{2}{|c|}{ Lag 2} & \multicolumn{2}{|c|}{ Lag 3} \\
\hline & Cons. & $\begin{array}{c}\text { Cons.+ } \\
\text { trend }\end{array}$ & Cons. & $\begin{array}{c}\text { Cons.+ } \\
\text { trend }\end{array}$ & Cons. & $\begin{array}{c}\text { Cons.+ } \\
\text { trend }\end{array}$ \\
\hline$q_{i t}$ & $0.018(0.507)$ & $\begin{array}{l}-0.082 \\
(0.468) \\
\end{array}$ & $0.568(0.974)$ & $2.127(0.983)$ & $0.987(0.838)$ & $0.968(0.833)$ \\
\hline$\Delta q_{i t}$ & $\begin{array}{l}-2.471 \\
(0.007) \\
\end{array}$ & $\begin{array}{l}-1.015 \\
(0.155)\end{array}$ & $\begin{array}{l}-0.018 \\
(0.493) \\
\end{array}$ & $2.268(0.988)$ & $\begin{array}{c}-0.528 \\
(0.299) \\
\end{array}$ & $1.155(0.876)$ \\
\hline$l_{i t}$ & $0.171(0.568)$ & $1.419(0.922)$ & $1.046(0.852)$ & $1.832(0.967)$ & $\begin{array}{l}-0.934 \\
(0.175)\end{array}$ & $\begin{array}{c}-2.745 \\
(0.003)\end{array}$ \\
\hline$\Delta l_{i t}$ & $\begin{array}{c}-2.088 \\
(0.018) \\
\end{array}$ & $\begin{array}{l}-1.588 \\
(0.056) \\
\end{array}$ & $0.553(0.710)$ & $1.939(0.974)$ & $\begin{array}{l}-3.281 \\
(0.001)\end{array}$ & $\begin{array}{l}-1.002 \\
(0.158) \\
\end{array}$ \\
\hline$m_{i t}$ & $0.922(0.822)$ & $\begin{array}{l}-1.048 \\
(0.147)\end{array}$ & $1.540(0.938)$ & $1.239(0.892)$ & $1.553(0.940)$ & $1.698(0.955)$ \\
\hline$\Delta m_{i t}$ & $\begin{array}{l}-3.719 \\
(0.000)\end{array}$ & $\begin{array}{l}-1.539 \\
(0.062)\end{array}$ & $\begin{array}{l}-1.404 \\
(0.080)\end{array}$ & $\begin{array}{l}-0.184 \\
(0.427)\end{array}$ & $\begin{array}{l}-0.261 \\
(0.397)\end{array}$ & $\begin{array}{l}-0.508 \\
(0.306)\end{array}$ \\
\hline
\end{tabular}

Notes: Lewandowski's (2007) Stata routine, pescadf, was used. The standardized z statistics are reported, along with the corresponding significance levels (in brackets). The null hypothesis is that the variable is non-stationary for all cross-sections. To account for a potential serial correlation, up to 3 lags were included in the CADF regression, of which two options were considered: a regression with a constant only or a constant plus trend. Pesaran (2007) provides more detail about the CIPS test.

Source: Own research.

From the results presented in Table 3, we can establish that the variables are not stationary. Performing the test on the first-differenced series, we cannot contest that the variables are integrated of order 1 (We found that the variables are also not $\mathrm{I}(2)$, therefore a formal test of cointegration (Westerlund, 2007) is not appropriate. As in Eberhardt and Teal (2012, 2013) and Eberhardt et al. (2010), an informal cointegration test is performed postestimation on the residuals using the stationarity test. The results are presented in continuation of the paper.).

Given the results of the cross-section dependence and stationarity tests, coupled with the results of the simulation studies from the literature (Chudik et al., 2011; Pesaran \& Tosetti, 2011) that have shown that CCEMG and AMG (Eberhardt \& Bond, 2009) performs better in the estimation of heterogenous non-stationary panel models with a cross-section dependence and cointegrated or non-cointegrated variables than conventional panel model estimators, we proceed with the estimation of models (4)-(6). We first test whether the returns to scale are constant. The results of the exercise are presented in Table 4 . The results imply that the hypothesis of CRS cannot be rejected, given that the parameter estimate for $\ln K_{i t}$ is not statistically significant. 
Table 4. A test of CRS*

\begin{tabular}{lcc}
\hline Variable & $\begin{array}{c}\text { Parameter estimates: } \\
\text { CCEMG estimator }\end{array}$ & $\begin{array}{c}\text { Parameter estimates: } \\
\text { AMG estimator }\end{array}$ \\
\hline$l_{i t}$ & .1552 & .1795 \\
\hline$m_{i t}$ & $(0.037)$ & $(0.009)$ \\
\hline \multirow{2}{*}{$K_{i t}$} & .5706 & .5803 \\
& $(0.000)$ & $(0.000)$ \\
\hline
\end{tabular}

Notes: * The CRS assumption is tested by estimating equation $q_{i t}=\alpha_{L i} l_{i t}+\alpha_{M i} m_{i t}+\gamma_{K i} l n K_{i t}+u_{i t}$ with the same error specification as in (4) and (5) (i.e., using the CCEM and AMG estimators) and then evaluating the sign and significance of the slope $\alpha \gamma_{K i}$. A negative and significant parameter estimate would indicate decreasing returns to scale.

Source: Own research.

With the constant returns to scale imposition, the results of models (4)-(6) are presented in Table 5 .

Table 5. The results of regression models (4)-(6)*

\begin{tabular}{|c|c|c|c|}
\hline Variable & $\begin{array}{l}\text { Parameter estimates } \\
\text { (elasticities): } \\
\text { FE estimator } \\
\text { (model (6)) }\end{array}$ & $\begin{array}{l}\text { Parameter estimates } \\
\text { (elasticities): } \\
\text { CCEMG estimator } \\
\text { (model (4)) }\end{array}$ & $\begin{array}{c}\text { Parameter estimates } \\
\text { (elasticities): } \\
\text { AMG estimator } \\
\text { (model (5)) }\end{array}$ \\
\hline$l_{i t}$ & $\begin{array}{r}.01252 \\
(0.598) \\
\end{array}$ & $\begin{array}{c}.2530 \\
(0.000)\end{array}$ & $\begin{array}{c}.2597 \\
(0.000)\end{array}$ \\
\hline$m_{i t}$ & $\begin{array}{r}.7110 \\
(0.000) \\
\end{array}$ & $\begin{array}{c}.5690 \\
(0.000) \\
\end{array}$ & $\begin{array}{c}.6138 \\
(0.000)\end{array}$ \\
\hline $\begin{array}{l}\text { Common } \\
\text { dynamic process }\end{array}$ & / & l & $\begin{array}{l}.78059 \\
(0.001)\end{array}$ \\
\hline Implied $\alpha_{K i}{ }^{\mathrm{a}}$ & 0.2765 & 0.1780 & 0.1265 \\
\hline \multicolumn{4}{|l|}{ Diagnostics } \\
\hline $\mathrm{RMSE}^{\mathrm{b}}$ & .0496 & 0.0126 & 0.0170 \\
\hline \multicolumn{4}{|c|}{ Residual diagnostics tests } \\
\hline $\mathrm{CD}$ test $\mathrm{t}^{\mathrm{c}}$ & $\begin{array}{c}1.33 \\
(0.182)\end{array}$ & $\begin{array}{c}-0.41 \\
(0.684)\end{array}$ & $\begin{array}{c}-0.64 \\
(0.520)\end{array}$ \\
\hline $\begin{array}{l}\text { Mean absolute } \\
\text { correlation }\end{array}$ & 0.489 & 0.279 & 0.262 \\
\hline Stationarity $^{\mathrm{d}}$ & $\begin{array}{c}0.282 \\
(0.611)\end{array}$ & $\begin{array}{l}-5.646 \\
(0.000)\end{array}$ & $\begin{array}{l}-1.862 \\
(0.031)\end{array}$ \\
\hline Autocorrelation $^{\mathrm{e}}$ & $\begin{array}{l}30.86 \\
(0.00)\end{array}$ & $\begin{array}{l}34.17 \\
(0.00)\end{array}$ & $\begin{array}{c}2.58 \\
(0.275)\end{array}$ \\
\hline
\end{tabular}

Notes: *The CCEMG and AMG models were estimated by the Stata routine, xtmg, in Eberhardt (2012). The robust option was applied; it provides less of a weight to the outliers in the data. The parameter estimate for the trend is not reported. In the CCEMG model, the trend was significant at the 5\% significance level for 7

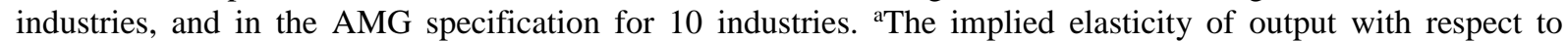
capital is calculated as $\alpha_{K i}=1-\alpha_{L i}-\alpha_{M i}$. ${ }^{\mathrm{b}} \mathrm{RMSE}$ denotes the root mean squared error. ${ }^{\mathrm{c}} \mathrm{The} \mathrm{CD}$ test is the cross-section dependence test of Pesaran (2004). The Stata routine xtcd of Eberhardt (2017) was also used. We also report the mean absolute correlation of the errors. 'Pesaran's (2007) CIPS test was performed with the Stata routine pescadf of Lewandowski (2007). The test statistic and the p-value for the CADF regression specification

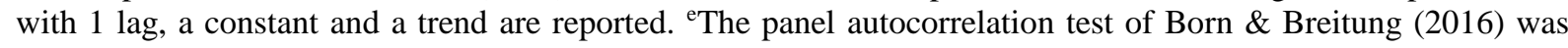
performed, testing for a serial correlation up to the second order. A Stata code xtqptest of Wursten (2016) was used. The null of the test is no autocorrelation up to order 2 , while the alternative is that there is some autocorrelation up to order 2. The test statistics and the p-value are reported.

Source: Own research. 
The estimated output elasticity, with respect to labor, ranges from 0.13 to 0.26 . The elasticity is almost identical for the CCEMG and AMG model specifications. The output elasticity with respect to intermediate inputs ranges between 0.57 and 0.71 , while the implied output elasticity with respect to capital ranges between 0.13 and 0.28 (We must note that the results of the CCEMG and AMG specifications present the consistent mean estimates of the parameters across industries. As noted by Pedroni (2007) and Eberhardt and Teal (2013), industry-specific estimates should not be viewed in isolation.). Evidently, a one percent increase in the intermediate inputs per capita share increases the output by more than the same relative increase in the labor per capita share. The results are in line with the studies that use a three-factor production function (Baptist \& Hepburn, 2013; Dobbelaere \& Mairesse, 2013). The estimated elasticities for the CCEMG and AMG models are also relatively close to the respective factor shares in output (see Table 6).

Turning now to the diagnostics and residual diagnostics tests, the CCEMG and AMG estimators perform better than the fixed effects estimator. The root mean squared error (RMSE) for the models, estimated by the CCEMG and AMG estimator, is smaller. Thus, it is a better statistical fit to the data. The CD test illustrates that cross-sectional dependence in the residuals is not an issue in the estimated models. The residual dependence, as measured by the mean absolute correlation, is considerably smaller for the CCEMG and AMG specifications of the model. The residuals of the fixed effects model are non-stationary, while for the CCEMG and AMG specification, they are stationary. As noted previously, the nonstationarity residuals render the t-statistics invalid (Kao, 1999; Eberhardt \& Teal, 2013). All these results imply that the CCEMG and AMG models that allow for the heterogeneity of the parameters and explicitly capture the cross-sectional dependence should be preferred to the fixed effects model specification. As suggested by Eberhardt et al. (2010), Eberhardt and Teal (2013), an autocorrelation test is performed to test for a possible model misspecification. The test results imply that there is some autocorrelation remaining in the residuals for the fixed effects and CCEMG models, while there is no residual autocorrelation in the AMG specification. Therefore, the AMG is our preferred model specification.

The estimates of the joint market imperfections parameter $(\tau)$ and price-cost mark-up $(\mu)$ are presented in Table 6 . The output elasticities with respect to labor and intermediate inputs are estimated by equations (4) and (5). The shares of the inputs in the total output $\left(\overline{v_{M \imath}}\right.$ and $\left.\overline{v_{L l}}\right)$ are estimated as the mean aggregate values of the investigated industries over the observed period.

Table 6. Average joint market imperfections parameter and price-cost mark-up estimate ${ }^{\mathrm{a}}$

Estimated parameter

Based on the CCEMG estimator of factor elasticities
Based on the AMG estimator of factor elasticities

\begin{tabular}{lcc}
\hline \multirow{2}{*}{$\tau^{\mathrm{b}}$} & .3553 & .4264 \\
& $(0.183)$ & $(0.056)$ \\
\hline \multirow{2}{*}{$\mu^{\mathrm{c}}$} & 1.186213 & 1.279486 \\
& $(0.190)$ & $(0.066)$ \\
\hline
\end{tabular}

Average value of factor (income) share in the national (i.e. across industries) output in the period 2000-2016 ${ }^{\mathrm{d}}$ :

- Intermediate inputs $\left(v_{M i}\right)=0.479685854$

- $\quad$ Labor $\left(v_{-}\right.$Li $)=0.304457283$

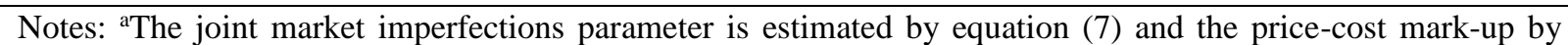
equation (8). ${ }^{b}$ Parameter estimate and the significance level (in parentheses), calculated by the delta method, are presented. 'Parameter estimate and the significance level of the test $\mu-1=0$ are presented. ${ }^{\mathrm{d}}$ The average is estimated as a mean value from the national accounts data. The data source is the Statistical Office of the Republic of Slovenia.

Source: Own research. 
The results show that the average estimate of the joint market imperfections parameter is positive for both estimators. It is statistically significant at less than the 10-percent (5.6percent) level, but only when the elasticities obtained by the AMG estimator are considered. As the AMG model specification is our preferred model, we conclude that the Slovenian economy, in the aggregate (as the average across the studied industries), is a case efficient bargaining labor market regime. As noted by Dobbelaere and Mairesse (2013), the workers and employers in such a regime bargain over wages and the level of employment, with the latter not being determined by the former, as in the case of a perfectly competitive labor market. The literature (see Fanti and Gori (2013) and references therein) shows that such a labor market regime is socially more efficient than some alternative labor market regimes. The average (across the industries) price-cost mark-up is 1.28, which indicates that the Slovenian (average across the industries) product market is imperfect (at the 6.6-percent significance level).

Dobbelaere and Mairesse (2013), Dobbelaere et al. (2015), Dobbelaere and Kiyota (2017), and Damoah (2017) illustrate that imperfect competition in the product market is predominant across the different industries. In the labor market, cross-country studies find either efficient bargaining or a perfect competition regime. Thus, the results for the Slovenian economy are not surprising. They are also similar to the results reported for France (Dobbelaere et al., 2015).

There are several implications of our findings. First, the results show that the homogeneity of production technology should not simply be assumed when estimating production functions. Indeed, as proven by the recent production function estimation literature, coupled with this study, the production technology across sectors, industries or countries is heterogenous. The relevance of the intermediate inputs in the world of scarce materials should not be downplayed in the estimation of a production function. Furthermore, the estimate joint imperfections parameter implies that competition in the Slovenian output and labor market is not perfect. This finding may be relevant for the industry policy in preparing measures that foster competition in the output and labor markets.

\section{Conclusion}

This paper estimates an aggregate production function for Slovenia over the period of 2000 through 2016, applying the CCEMG and AMG estimators. We illustrate that applying conventional panel data estimators can yield misleading results. By the diagnostics tests, we determine that the AMG is our preferred specification for the production function. Our results show that the constant returns to scale cannot be rejected and that the production function is heterogenous across industries. This has important practical implication for the economic policy and for the business practitioners: a great care is needed when any aggregation is performed in estimation of production function. In the three-factor production function, including labor, capital and intermediate inputs, we found that the elasticity of the output with respect to labor is about half the size of the elasticity of the output with respect to the intermediate inputs and about one and a half the size of the elasticity of the output with respect to capital. Applying the methodology of Dobbelaere and Mairesse (2013), we found that the joint market imperfections parameter indicates an incomplete product and incomplete (efficient bargaining) labor market. The future research could complement the findings of this paper by analysis of the inter- and intra-industry differences in the labor and product market imperfections applying production function approach and paying close details to econometric modeling of panel data with a possible heterogeinty and cross-section dependence. 


\section{Acknowledgement}

This research has been supported by Slovenia Research Agency (research core funding P5-0023 (A)).

\section{References}

Abramowitz, M. (1956). Resource and Output Trends in the United States since 1870. American Economic Review, 46(2), 5-23.

Baccianti, C. (2013). Estimation of Sectoral Elasticities of Substitution Along the International Technology Frontier. ZEW Discussion Paper No. 13-092, Centre for European Economic Research.

Baltagi, B.H. (2005). Econometric Analysis of Panel Data models. Third Edition. Chichester: John Wiley \& Sons Ltd.

Banerjee, A., \& Duflo, E. (2005). Growth theory through the lens of development economics. In: Handbook of economic growth, edited by Aghion, O., and Durlauf, S., 473-552. New York: North Holland.

Banerjee, A., \& Carrion-i-Silvestre, J. L. (2017). Testing for Panel Cointegration Using Common Correlated Effects Estimator. J. Time Ser. Anal., 38(4), 610-636.

Baptist, S., \& Hepburn C. (2013). Intermediate inputs and economic productivity. Philosophical Transactions of the Royal Society, A: Mathematical, Physical and Engineering Sciences, 371: 20110565.

Baumol, W.J. (1967). Macroeconomics of unbalanced growth: the anatomy of urban crisis. American Economic Review, 57(3), 415-426.

Baumol, W.J., Blackman, S.A.B., \& Wolff, E.N. (1985). Unbalanced growth revisited: asymptotic stagnancy and new evidence. American Economic Review, 75(4), 806-817.

Benos N., Mylonidis, N., \& Zotou, S. (2017). Estimating production functions for the US states: the role of public and human capital. Empirical Economics, 52(2), 691-721.

Bournakis, I., Christopoulos, D., \& Mallick, S. (2017). Knowledge Spillovers and Output per Worker: An Industry-Level Analysis for OECD Countries. Economic Inquiry, 56(2), 1028-1046.

Carrion-i-Silvestre, J. L., \& Surdeanu, L. (2012). Estimation of production functions: The Spanish regional case. XV Encuentro de Economia Aplicada. La Coruña, Spain, June 7-8. Retrieved from http://encuentros.alde.es/anteriores/xveea/trabajos/c/pdf/193.pdf.

Carrion-i-Silvestre, J. L., \& Surdeanu, L. (2016). Productivity, Infrastructure and Human Capital in the Spanish Regions. Spatial Economic Analysis, 11(4), 365-391.

Chudik, A., \& Pesaran, M.H. (2013). Large Panel Data Models with Cross-Sectional Dependence: A Survey. Federal Reserve Bank of Dallas Globalization and Monetary Policy Institute Working Paper No. 153.

Chudik, A., Pesaran, M.H., \& Tosetti, E. (2011). Weak and Strong Cross Section Dependence and Estimation of Large Panels. Econometrics Journal, 14(1), C45-C90.

Constantini, M., \& Destefanis, S. (2009). Cointegration analysis for cross-sectionally dependent panels: The case of regional production functions. Economic Modelling, 26(2), 320-327.

Damoah, A. K. (2017). Markups, Markets Imperfections, and Trade Openess: Evidence from Ghana. Working Papers - Economics N. 15/2017, Universita' degli Studi di Firenze, Dipartimento di Scienze per l'Economia e l'Impresa.

D’Auria, F., Denis, C., Havik, K., Mc Morrow, K., Planas, C., Raciborski, R., Röger, W., \& Rossi, A. (2010). The production function methodology for calculating potential growth 
rates and output gaps. European Commission Economic and Financial Affairs Directorate-General Economic Papers 420.

De Loecker, J., \& Warzynski, F. (2012). Markups and Firm-Level Export Status. American Economic Review, 102(6), 2437-2471.

Dobbelaere, S., \& Mairesse, J. (2013). Panel Data Estimates of the Production Function and Product and Labor Market Imperfections. Journal of Applied Econometrics, 28(1): 1-46.

Dobbelaere, S., Kiyota, K., \& Mairesse, J. (2015). Product and labor market imperfections and scale economies: Micro-evidence on France, Japan and the Netherlands. Journal of Comparative Economics, 43(2), 290-322.

Dobbelaere, S., \& Kiyota, K. (2017). Labor market imperfections, markups and productivity in multinationals and exporters. TI Discussion Paper Series, Vol. 17, No. 113/V. Amsterdam: Tinbergen Institute.

Durlauf, S.N. (1993). Nonergodic economic growth. Review of Economic Studies, 60(2), 349366.

Durlauf, S.N., Kourtellos, A., \& Minkin A. (2001). The Local Solow Growth model. European Economic Review, 45(4-6), 928-940.

Eberhardt, M. (2012). Estimating panel time-series models with heterogeneous slopes. The Stata Journal, 12(1), 61-71.

Eberhardt, M. (2017). XTCD Stata routine. Retrieved from https://sites.google.com/site/medevecon/code\#TOC-xtcd.

Eberhardt, M., \& Bond, S. (2009). Cross-section dependence in nonstationary panel models: a novel estimator. MPRA Paper No. 17870.

Eberhardt, M., \& Teal, F. (2010a). Growth and Development in an Empirical Dual Economy. Paper presented at the CSAE Conference 2010, Economic Development in Africa. Retrieved from http://ex-iis.csae.ox.ac.uk/conferences/2010-EdiA/papers/275Eberhardt.pdf.

Eberhardt, M., \& Teal, F. (2010b). Productivity Analysis in Global Manufacturing Production. University of Oxford Department of Economics Discussion Paper Series No. 515.

Eberhardt, M., Banerjee, A., \& Reade, J.J. (2010). Panel Estimation for Worriers. University of Oxford Department of Economics Series Working Papers No. 514.

Eberhardt, M., \& Teal, F. (2012). Structural Change and Cross-Country Growth Empirics. The World Bank Economic Review, 27(2), 229-271.

Eberhardt, M., \& Teal, F. (2013). No Mangoes in the Tundra: Spatial heterogeneity in Agricultural Productivity Analysis. Oxford Bulletin of Economics and Statistics, 75(6), 914-939.

Eberhardt, M., \& Teal, F. (2017). The Magnitude of the Task Ahead: Macro Implications of Heterogeneous Technology. Discussion Papers 2017-16, University of Nottingham, GEP.

Eurostat. (2008). Statistical Classification of Economic Activities in the European Community, Rev. 2. Luxembourg: Eurostat.

Fanti, L., \& Gori, L. (2013). Efficient bargaining versus right to manage: A stability analysis in a Cournot duopoly with trade unions. Economic Modelling, 20, 205-211.

Hall, R.E. (1988). The relationship between price and marginal cost in US industry. Journal of Political Economy, 96(5), 921-947.

Hall, B.H., Mairesse, J., \& Mohnen, P. (2009). Measuring the returns to R\&D. NBER Working Paper Series No. 15622.

Han, J. (2016). Essays on Treatments of Cross-Section Dependence in Panel Data Models. A $\mathrm{PhD}$ Thesis. Rice University. Retrieved from https://scholarship.rice.edu/handle/1911/96543. 
Holly, S., Pesaran, M. H., \& Yamagata, T. (2010). A spatio-temporal model of house prices in the USA. Journal of Econometrics, 158(1), 160-173.

Jemec. N. (2012). Output gap in Slovenia: What can we learn from different methods? Banka Slovenije Prikazi in analize 4/12, Ljubljana: Bank of Slovenia.

Jongen, E. L. W. (2004). An Analysis of Past and Future GDP Growth. IER Working Paper No. 2004. Ljubljana: Institute for Economic Research.

Kao, C. (1999). Spurious regression and residual-based tests for cointegration in panel data. Journal of Econometrics, 65(1), 9-15.

Krüger, J.J. (2008). Productivity and Structural Change: A Review of the Literature. Journal of Economic Surveys, 22(2), 330-363.

Laitner, J. (2000). Structural change and economic growth. Review of Economic Studies, 67(3), 545-561.

Lewandowski, P. (2007). PESCADF: Stata module to perform Pesaran's CADF panel unit root test in presence of cross section dependence. Retrieved from http://econpapers.repec.org/software/bocbocode/s456732.htm.

Lewis, W.A. (1954). Economic development with unlimited supplies of labor. The Manchester School, 22(2), 139-191.

Mankiw, N.G., Romer, D., \& Weil, D.N. (1992). A Contribution to the Empirics of Economic Growth. The Quarterly Journal of Economics, 107(2), 407-437.

Molnar, M. (2010). Measuring Competition in Slovenian Industries: Estimation of Mark-ups. OECD Economics Department Working Papers, No. 787, OECD Publishing, Paris.

Mundlak, Y. (1993). On the Empirical Aspects of Economic Growth Theory. American Economic Review, 83(2), 415-420.

Mundlak, Y., Butzer, R., \& Larson, D.F. (2008). Heterogenous Technology and Panel Data. The Case of the Agricultural Production Function. Journal of Development Economics, 99(1), 139-149.

Norrbin, S.C. (1993). The Relation between Price and Marginal Cost in U.S. Industry: A Contradiction. Journal of Political Economy, 101(6), 1149-1164.

Novak, M., \& Bojnec, Š. (2005). Human Capital and Regional Economic Growth in Slovenia. Managing Global Transitions, 3(2), 157-177.

Novak, M. (2003). The Returns to Education: Some Empirical Findings for Slovenia. Managing Global Transitions, 1(2), 153-167.

Pedroni, P. (2007). Social Capital, Barriers to Production and Capital Shares: Implications for the Importance of Parameter Heterogeneity from a Nonstationary Panel Approach. Journal of Applied Econometrics, 22(2), 429-451.

Pesaran M.H. (2004). General Diagnostic Tests for Cross Section Dependence in Panels. IZA Discussion Paper No. 1240.

Pesaran M.H. (2006). Estimation and Inference in Large Heterogeneous panels with a multifactor error structure. Econometrics, 74(4), 967-2012.

Pesaran, M. H. (2007). A Simple Panel Unit Root Test in the Presence of Cross Section Dependence. Journal of Applied Econometrics, 22(2), 265-312.

Pesaran, M. H. (2015). Testing Weak Cross-Sectional Dependence in Large Panels. Econometric Reviews, 34(6-10), 1089-1117.

Pesaran, M.H., \& Smith, R. (1995). Estimating long-run relationships from dynamic heterogenous panels. Journal of Econometrics, 68(1), 79-113.

Pesaran, M. H., Tosetti, E. (2011). Large panels with common factors and spatial correlation. Journal of Econometrics, 161(2), 182-202.

Phillips, P.C.B., \& Moon, H.R. (1999). Linear regression limit theory for nonstationary data. Econometrica, 67(5), 1057-1112. 
Roeger, W. (1995). Can imperfect competition explain the differences between primal and dual productivity measures? Estimates for U.S.Manufacturing. The Journal of Political Economy, 103(2), 316-330.

Solow, R.M. (1957). Technical Change and the Aggregate Production Function. The Review of Economics and Statistics, 39(3), 312-320.

Statistical Office of the Republic of Slovenia. (2017). Methodological Explanation - Nonfinancial Assets. Available at: http://www.stat.si/statweb/File/DocSysFile/8101, referred on $03 / 06 / 2018$.

Temple, J. (2005). Dual economy models: A primer for growth economists. The Manchester School, 73(4), 435-478.

Uy, T., Yi, K-M., \& Zhang, J. (2013). Structural Change in an Open Economy. Journal of Monetary Economics, 60(6), 667-682.

Vollrath, D. (2009). The dual economy in long-run development. Journal of Economic Growth. 14(4), 287-312.

Westerlund, J. (2007). Testing for Error Correction in Panel Data. Oxford Bulletin of Economics and Statistics, 69(6), 709-748.

Wursten, J. (2016). XTQPTEST: Stata module to perform Born \& Breitung Bias-corrected LM-based test for serial correlation. Statistical Software Components S458219, Boston College Department of Economics,

Wursten, J. (2017). XTCDF: Stata module to perform Pesaran's CD-test for cross-sectional dependence in panel context. Statistical Software Components S458385, Boston College Department of Economics. 